\title{
The Research on Inheritance and Transcendence Pathway of Confucian Ecological Thought*
}

\author{
Yan Li \\ School of Marxism \\ Hainan College of Economics and Business \\ Haikou, China
}

\author{
Xiang Li \\ School of Marxism \\ Hainan College of Economics and Business \\ Haikou, China
}

\begin{abstract}
The Confucian ecological thought contains a rich ecological culture, but due to the constraints of the development of the times, it has historical limitations. Inheriting and developing Confucian traditional ecological thought is the wisdom support to dissolve the current global ecological environment crisis. The thought is the inherent need to realize the creative transformation of Confucian ecological thoughts and the innovative development of ecological civilization in the new era. The thought is also the value support to realize the construction of a beautiful China. Therefore, China must grounds itself on reality, keeps the origin in mind, absorbs foreign thoughts, be future-oriented, and make creative transformation and innovative development, hence to achieve the inheritance and transcendence of the excellent Confucian traditional ecological thought theory and practice.
\end{abstract}

Keywords - Confucian ecological thought; inheritance; transcendence

\section{INTRODUCTION}

Culture is the blood of the nation and the spiritual home of the people. "The Chinese nation has always respected nature and loved nature. The Chinese civilization that lasts for more than 5,000 years has bred the rich ecological culture". ${ }^{1}$ The traditional ecological thought of Confucianism is one of the representatives. However, due to the constraints of the development of the times and other conditions, it has historical limitations. Only by creatively realizing the inheritance and transcendence of Confucian traditional ecological thought can it truly become the "source of fresh water" for ecological civilization construction in the new era.

*Fund: This article is the research results for subjects of party building and research on ideological and political education in Hainan College of Economics and Business of 2018: the study on the integration of Chinese excellent traditional culture and ideological and political education of college students (Project Number: hnjmk2018614); the 2018 Hainan higher education and teaching reform research project: research on the integrated synergy model of ecological civilization education for college students (Project Number: hnjg2018-86); and the 2019 Hainan Philosophy and Social Science Planning Project (specialize in ideology and politics): Research on the Cultivation Mechanism of Ecological Citizens from the Perspective of beautiful Hainan (Project Number: hnsz2019-45).

$\mathrm{Xi}$ Jinping. Promoting the Construction of Ecological Civilization in China to a New Level [J]. Qiushi, 2019 (3).

\section{THE CONTENTS AND CHARACTERISTICS OF CONFUCIAN TRADITIONAL ECOLOGICAL THOUGHT}

Chinese culture has a long history and is brilliant. In the development of civilization over 5,000 years, Confucian traditional ecological thoughts were conceived by the scholars of Confucius, Mencius, and Xuncius and their descendants by exploring the relationship between natural phenomena and human society, and understanding the social evolution process from ancient times to the present. Although they have formed their own theories, their theories all start from the morals of righteousness. The theories also pay attention to the harmonious relationship between man and nature, in order to realize the existence value of "people", and form a unique Confucian traditional ecological thought.

\section{A. Ecological and Natural View of "Harmony Between Man and Nature"}

"Harmony between man and nature" is the core and unique concept of traditional Chinese culture, which represents the characteristics of traditional Chinese culture, and is the logical starting point of Confucianism. "The Book of Changes", the head of the Six Classics of Confucianism, is known as "the source of the principles". It points out that the nature law of heaven is a combination of yin and yang, and everything in the universe is composed of two elements yin and yang and the atmosphere. The environment is the combination of tough mountains and gentle water, and the mountains and rivers are nature, whether rigid or flexible. The interpersonal relationship is a combination of kindheartedness and justice. Man is the product of heaven and earth. It is necessary to follow the law of nature and the "three talents principle" in order to achieve the goal that everything in the world is endless and "the harmony among heaven, earth and men," thus laying the tone of Confucian ecological thought. Confucius proposed that the laws of nature do not shift from the will of the heavens and people. Once the state of neutrality is reached, the heavens and the earth will return to their place and everything will grow and develop. It further explained that the operation of the heaven and the earth is determined by the laws of nature and will not be changed based on anyone's will. Mencius proposed that man should love their families and love the people, love the people hence love all things; Xuncius believed that the heavens and earth were the ancestors of all things and the 
origin of life, and the heavens and earth were created by yin and yang. Everything is the result of interaction between yin and yang and the growth of everything is natural. The nature itself has its objective regularity, and it is pointed out that the relationship between man and nature is the core of the relationship between man and nature. On the basis of inheriting the thoughts of his predecessors, Dong Zhongshu, the famous Western Han thinker, formally put forward the concept of "harmony between man and nature", clearly pointed out that nature and man are two kinds of things, and compared nature and man to each other, and reached the conclusion that nature and man are unified. At this point, the relationship between nature and man has changed from a purely natural view to humanized nature, and man and nature are truly one in the humanistic sense. In short, Confucius, Mencius, and Zhuzi and their descendants proceeded from the dimension of the relationship between man and nature to explore the relationship between heaven, earth, and people, so as to realize the ideal state of "the harmony between heaven and man". Therefore, Confucian traditional ecological thought emphasizes not only a view of nature and the universe, but also a simple view of ecology and values of life.

\section{B. The Ecological Ethics of "Benevolence"}

Kindheartedness, as the first principle of Five Constant Virtues of Confucianism, is the core of Confucianism. In the traditional ecological thought of Confucianism, Confucius proposed that the benevolent should "love people" and "love things". He believed that all things in the world are the material basis for human beings and human beings should treat all things amicably and carefully. He advocated that people use only bamboo rods to fish, not nets; only shoot birds that fly, not birds that stay overnight. This spontaneous expression of respect and love for natural life is the ultimate destination of Confucius' ecological thoughts, and it reflects the ancient simple ideas of sustainable development. Mencius not only elaborates the relationship between love, benevolence, and relatives, but also emphasizes that "shengsheng" as a natural emotion is the logical starting point of "kinship" and the starting point and root of benevolence. Further, the expansion of the family into society, and then from society to nature, makes benevolence an ecological moral meaning. Xuncius completely rejected the traditional destiny theory of natural will, not only pointing out that the movement of nature has its objective laws, but also clarifying that the blessings of mankind are only the inevitable result of natural processes under the manmade adaptation or interference. Not only the heaven should be returned to nature, but also the people should be returned to the society. The Neo-Confucianism scholars in Song Dynasty Cheng Hao and Cheng Yi pointed out that man is born of heaven and earth and is a member of heaven and earth, and one must put heaven and earth in his own heart and establish a way of mutual friendship with all things on the earth. Those who are benevolent must love everything and respect life.

\section{The Ecological Protection View of "Self-control and Abstinence"}

In the agricultural society, under the influence and restriction of low productivity and underdeveloped technology, at that time people had mysterious cognition of lightning, thunder, mountains, rivers, and seas, and the divine worship therefrom. Therefore, Confucius, Mencius, Xuncius and the descendants emphasized It is an important content of traditional Confucianism to abstain from selfrestraint and respect the nature. It is also the requirements and guidelines of Confucius, Mencius and Xuncius for mankind to protect nature. Confucius elevated the "forbidden time to the height" to the level of filial piety, clearly pointing out that logging and hunting in inappropriate time is not filial piety. If humans cannot respect nature or even disrupt the laws of nature, they will offend nature and will eventually be punished by nature. Keeping awe and obeying nature reflects the simple environmental protection thoughts of the ancients. On this basis, Mencius suggested that human beings can only ensure natural vitality if they control their desires and conform to the laws of the growth and development of all things, and give them time to rest and regrowth. Xuncius not only warned people to obey the natural laws, but also regarded the protection of ecology as the "Sacred King's Outline". He emphasized that the rulers of the country should develop a system to protect natural resources. In short, they should propose to follow the laws of nature, restrain people's desires and use natural resources on appropriate time within appropriate amount, and maintain awe of nature, and then achieve conscious maintenance of ecological nature.

By combing the content, it is not difficult to discover the characteristics of the traditional ecological thought of Confucianism: First, the implementation and development of the concept of "harmony between man and nature" in "The Book of Changes". The relationship between man and nature should be dealt dialectically. The inner harmony between man and nature is acknowledged and the self-control and abstinence is advocated hence to maintain a harmonious and symbiotic relationship with nature. The second is to streamline the relationship between man and nature through "benevolence" and warn people that they must respect nature and obey nature in order to avoid punishment. The third is to advocate that people adhere to the bottom line, standardize human activities, realize the harmonious coexistence of man and nature, and ultimately achieve the ideal state of continuous development of man and nature. In short, wise man such as Confucius and Mencius, with strong sense of difficulties and risks and awareness of social responsibility, explored the ultimate value and significance of human existence and formed the traditional ecological thought of Confucianism. The rational factors and eternal value contained in it still have a strong guiding influence on the construction of socialist ecological civilization.

\section{THE INHERITANCE AND TRANSCENDENCE VALUE OF CONFUCIAN ECOLOGICAL THOUGHT}

The traditional ecological thought of Confucianism reflects the profound understanding and dialectical grasp of the relationship between man and nature by ancient Chinese 
Today, when the ecological crisis is serious, the purpose of ecological protection cannot be achieved only by emphasizing self-control and self-restraint. It must advances with the times, deeply explores the value connotation of the excellent traditional ecological thoughts of China, and learns from the beneficial elements of western ecological thoughts to continuously provide Confucian with the new era connotation and modern expression forms. Only in this way can traditional ecological thoughts further rejuvenate the vitality and vigor of traditional ecological thoughts.

\section{Resolve the Current Global Ecological and} Environmental Crisis

A history of human civilization is the development history of the relationship between man and nature. If take the primitive civilization and agricultural civilization as "yellow civilizations", the industrial civilization should be called "black civilization", because it follows a path of pollution first and then governance. Since the Industrial Revolution, with the continuous improvement of productivity and the rapid development of science and technology, mankind has made great achievements in the concept of transforming nature and even conquering nature, but has also made great destruction of ecological environment. In this regard, Engels pointed out, "We must not be overly intoxicated by humanity's victory over nature. For every such victory, nature retaliates against us." ${ }^{2}$ What happened to the world? What should the people do? "History and reality have proven that there is only one civilization in the world that is sustainable and is closest to ecological civilization, and this civilization is the Chinese civilization; there is only one country in the world that can withstand the test of sustainable development, and this country is China." ${ }^{3}$ Therefore, In this sense, the wisdom to support the inheritance and development of Confucian traditional ecological thoughts to resolve the current global ecological and environmental crisis is Chinese wisdom and China's solution to the global ecological, environmental and resource crisis.

\section{B. Inheriting and Developing the Traditional Ecological}

Thought of Confucianism Is the Inherent Need to

Achieve Its Creative Transformation and Innovative

Development

"Where history begins, where should the ideological process begin?" ${ }^{4}$ The development of any country and human civilization cannot be separated from its own history and traditions, and modern inheritance and development on the spiritual level, such as ecological thought, need more help from the inseparable tradition. Although the traditional ecological thought of Confucianism has played a positive role in promoting the development of social ecology at that time, due to the factors of the times, it is inevitable that there is mysterious cognition of the relationship between humans and nature, and the divine worship. The thought has obvious limitations such as intuition, empiricism and mystery, etc.

Marx and Engels. Marx and Engels Selected Works (Volume 4) [M]. People's Publishing House, 1995:383.

Compilation: the Fifteenth Treatise on Contemporary Marxist Political Economy [M]. China Renmin University Press, 2016:135.

Marx and Engels. Marx and Engels Selected Works (Volume 2) [M]. People's Publishing House, 1995:43.

\section{Inheriting and Developing Confucian Traditional Ecological Thought is the Value Support for Realizing the Construction of Ecological Civilization in the New Era and the Construction of Beautiful China}

"If the ecology is prosperous, the civilization will also be prosperous; if the ecology is decaying, the civilization will also be decaying." How to guide people to establish awareness of ecological environment protection and ecological literacy, consciously become ecological citizens, to become active practitioners of socialist ecological civilization and the builders of beautiful China, and promote the formation of a new modernization pattern of harmonious development between man and nature? This is a major question that must be answered in the process of realizing the national dream of the great rejuvenation of the Chinese nation. General Secretary Xi Jinping pointed out many times: "Realizing a new era of ecological civilization and building a dream of the great rejuvenation of the Chinese nation." ${ }^{5}$ Therefore, inheriting and developing the traditional ecological thought of Confucianism is the value support for realizing the ecological civilization construction and the construction of beautiful China in the new era.

\section{THE INHERITANCE AND TRANSCENDENCE PATHWAY OF CONFUCIAN TRADITIONAL ECOLOGICAL THOUGHT}

The inheritance of Confucian traditional ecological thought cannot be retrospective; the development of Confucian traditional ecological thought cannot be simply denied; the transcendence of Confucian traditional ecological thought cannot be carried out in isolation. The inheritance and transcendence of Confucian traditional ecological thought must be combined with the modernization and transformation of traditional Chinese culture as a whole, and integrated with western ecological ethical thoughts to achieve the transcendence of excellent Confucian traditional ecological ideological theories. In the practice of ecological civilization construction and the construction of beautiful China, it is necessary to surpass the traditional ecological thoughts and practices of outstanding Confucianism and contribute Chinese wisdom and Chinese solutions to the development of human ecological civilization.

Xi Jinping. The Book of Xi Jinping's Important Speeches [M] Learning Publishing House, 2016:230. beautiful China is an important part of achieving the Chinese 
A. The Implementation of Xi Jinping's Thoughts on Ecological Civilization, the Establishment of a New Type of Relationship Between Man and Nature, and the Realization of the Transcendence of the Excellent Confucian Traditional Ecological Thoughts and Theories

In the new era, China has become a major economy power, but rather an economic power. For a long time, China's economy has adhered to the extensive development mode characterized by high input, high consumption and high pollution, which leads to the deterioration of the ecological environment in China. As "the harmony between man and nature" is a proposition in philosophy, "nature" and "men" should be regarded as an unseparated entity and they have inner connections. Undoubtedly, this will provide a reasonable positive idea for solving the relationship between "nature" and "men" and solving the serious "ecological" problems that exist at present. ${ }^{6}$ Therefore, it will be necessary to take Xi Jinping's ecological civilization thought as the guide, revere and respect nature, conform and protect nature, establish the new relationship between man and nature, construct the life community of man and nature, and seek the methods to solve the ecological problems while transcending the traditional theory of ecological thought of Confucianism.

\section{B. To Realize the Creative Transformation and Innovative Development of Confucian Traditional Ecological Thought Basing on Contemporary Era and Future}

Insisting on creative transformation and innovative development is not only the important principle of carrying out the project of inheritance and development of Chinese excellent traditional culture, but also the main way of carrying out the project of inheritance and development of Chinese excellent traditional culture. It requires people to do following things. On the one hand, it is necessary further excavate the modern value of the traditional Confucian ecological thought, and discard the dross and inherit the essence of the traditional ecological idea of "the harmony between nature and man"; on the other hand, it will also be significant to absorb the cultural implication of the traditional Confucian ecological thought, and incorporate the reasonable contents of the western ecological thought, and on that basis, it is a must to complement the traditional Confucian ecological thought with the western ecological thought to realize the transformation and innovation of the connotation of outstanding Confucian traditional culture. Only in this way can people endow the ecological civilization with national characteristics and enhance the cultural self-confidence and cultural influence. Besides, the cultural self-confidence is a more fundamental, broader and deeper self-confidence. It integrated with viatic selfconfidence, theoretical self-confidence and systematic selfconfidence in the great practice of socialism with Chinese characteristics.

Tang Yijie. The Study of the Harmony Between Man and Nature [J]. History of Chinese philosophy, 2005 (2).

\section{The Integration with the Socialist Ecological Civilization and the Construction of a Beautiful China, and the Realization of the Transcendence of the Traditional Ecological Thought and Practice of the Excellent Confucianism}

As the fundamental way of human existence, practice is not only the basic activity of humans to transform the world, but also the basic content of human social life. Human society is advancing in continuous social practice. Therefore, Marx believes that "the nature of social life is practice". Building an ecological civilization is the millennium plan and fundamental plan for the sustainable development of the Chinese nation. In May 2018, the timetable and road map for the construction of a beautiful China were clearly presented at the National Ecological Environment Protection Conference. In the new era, to inherit and transcend the traditional ecological ideas of Confucianism, it must be integrated with the socialist ecological civilization and the practice of building a beautiful China. "The thought should constantly deepen its knowledge and constantly sum up experiences and constantly realize the beneficial interactions between theoretical innovation and practical innovation in accordance with changes of the times and development of practice".?

\section{CONCLUSION}

In conclusion, the Confucian ecological thought proposed by Confucius, Mencius and Xuncius and etc. "has thought and expressed the fundamental problems of human existence and development. Its wisdom ray penetrates history, its ideological value spans time and space, and it has become a spiritual wealth shared by mankind". The Confucian ecological thought is not only the spiritual homeland that the Chinese nation can never part, but it also has worldwide cultural significance. It is achieved by basing on reality, not forgetting the origin, absorbing foreign thoughts, and facing the future. Also, it should combine with Marxist ecological outlook and guide by Xi Jinping's ecological civilization thought. To make it compatible with the realistic culture, play in the same frequency as the social development of the new era, and serve the task of cultural people, the new concept of revering, respecting, obeying and protecting nature should be established, the new relationship between man and nature should set up, the human and natural life community should be built up and there should be innovative transformation and development.

\section{REFERENCES}

[1] Xi Jinping. Promoting the Construction of Ecological Civilization in China to a New Level [J]. Qiushi, 2019 (3). (in Chinese)

[2] Marx and Engels. Marx and Engels Selected Works (Volume 4) [M] People's Publishing House, 1995:383. (in Chinese)

[3] Compilation: the Fifteenth Treatise on Contemporary Marxist Political Economy [M]. China Renmin University Press, 2016:135. (in Chinese)

Xi Jinping. Adhere to the Dialectical Materialism World Outlook Methodology to Improve the Ability to Solve the Basic Problems of China's Reform and Development
[OL]. http://www.xinhuanet.com/politics/2015-01/24/c_127416715.htm. 


\section{PRESS}

[4] Marx and Engels. Marx and Engels Selected Works (Volume 2) [M]. People's Publishing House,1995:43. (in Chinese)

[5] Xi Jinping. The Book of Xi Jinping's Important Speeches [M]. Learning Publishing House,2016:230. (in Chinese)

[6] Tang Yijie.The Study of the Harmony Between Man and Nature[J]. History of Chinese philosophy,2005 (2). (in Chinese)

[7] Jinping. Adhere to the Dialectical Materialism World Outlook Methodology to Improve the Ability to Solve the Basic Problems of China's Reform and Development [OL]
[O http://www.xinhuanet.com/politics/2015-01/24/c_127416715.htm. (in Chinese) 